\title{
REVIEW: TERELAK J. F. (2017). STRES ŻYCIA. PERSPEKTYWA PSYCHOLOGICZNA. WARSZAWA: WYDAWNICTWO NAUKOWE UNIWERSYTETU KARDYNAŁA STEFANA WYSZYŃSKIEGO
}

\author{
Dominik GOŁUCH \\ Cardinal Stefan Wyszynski University in Warsaw, Institute of Psychology, Warsaw, Poland
}

Source of support: Own sources

Author's address: D. Gołuch, Cardinal Stefan Wyszynski University in Warsaw, Institute of Psychology, Dewajtis 5 Street, 01-815 Warsaw, Poland, e-mail: d.goluch@uksw.edu.pl

In 2017, the work of Prof. Jan F. Terelak, PhD, Stres życia. Perspektywa psychologiczna (The Stress of Life. A Psychological Perspective) was published. The title refers directly to the groundbreaking work by Hans Selye - Stress of Life, because the author started his work in 2013 and wanted to commemorate the 50th anniversary of the publication of the Polish translation of Selye's book [1]. Review of the scientific book by Prof. Jan F. Terelak, PhD was written by Rev. Prof. Zenon Uchnast, PhD and Iwona Niewiadomska, PhD, Prof. of the Lublin Catholic University. This is another publication in the author's achievements concerning the broadly understood psychology of stress. Previous works were addressed to professional psychologists, while the present study is a textbook and is addressed to students of social, pedagogical and medical sciences, as well as representatives of various professions dealing with the so-called stress factors. The contents and layout of the book have been adapted for teaching purposes: each chapter ends with a summary, revision questions and bibliographic guidelines. In order to make it more attractive, many colorful graphics and photos have been included.

The content has been ordered in 5 chapters, constituting a logical whole. The first chapter describes the concepts of stress, broken down into models: biological, medical, psychological, psychosocial. In addition to the general characteristics of each group of stress theory, the author describes in details 16 models of stress and generally presents four models of occupational stress. The second chapter describes the sources of stress. The author categorizes them into four groups, however these are

References: 2 • Full-text PDF: http://www.pjambp.com • Copyright @ 2017 Polish Aviation Medicine Society, ul. Krasińskiego 54/56, 01-755 Warsaw, license WIML • Indexation: Index Copernicus, Polish Ministry of Science and Higher Education 
not arbitrarily determined categories, but they result from the relevant theory. These categories are ecological, chronobiological, psychological and organizational sources. The next, third chapter describes the responses to stress. As a starting point of this chapter, the author cites a model of response to stress of J. Reykowski. Then, he describes the symptoms of response to incidental, chronic, traumatic stress. Separate sub-chapters are devoted to specific reactions: alcoholism and toxicomania as well as self-destruction and socio-destruction. The fourth chapter refers to the methods of dealing with stress, including stress resistance (biological and psychological), coping skills as well as individual, social and institutional forms of dealing with stress. The theoretical models as well as empirical and practical aspects were discussed. The last chapter describes psychological moderators of stress and of coping with it in a synthetic manner, particularly the temperament, cognitive styles, personality and selected personality variables (locus of control, self-esteem, fear as a feature, basic hope, sense of meaning, optimism and pessimism), other psychological constructs (A type behaviors, sense of coherence, emotional intelligence, social competences, psychological gender) and responses to chronic stress (job burnout, alcoholism). The author repeatedly points out in the chapter that the described variables are re- lated to the way of experiencing and responding to stress only to a certain extent, because also situational variables, which can significantly change human behavior, are important.

When reading the book by Prof. Jan F. Trelak, $\mathrm{PhD}$ it is difficult not to compare it with the previous works. On the one hand, the publication is more visually attractive, more clear, and thanks to the presence of summaries, it is easier to organize and remember the material. On the other hand, some of the elements present in the previous books have been omitted here. This is most evident in the absence of a comprehensive review of research, present in the work Człowiek i stres [2]. However, taking into account the target group, i.e. students and people professionally dealing with stress, this seems partially justified. Moreover, some of the discussed issues have been presented in a more synthetic manner than before, which may also help in the reception of the book. To sum up, the publication presents the phenomenon of stress in a comprehensive way, pointing out the complexity of the issue. The author presents both the theoretical fundamentals, as well as the directions of empirical research conducted. All the above mentioned elements make that the "dream of a colorful textbook" in the field of psychology of stress mentioned by the author in the foreword to the book can be considered as fulfilled.

\section{REFERENCES}

1. Selye H. The stress of life. New York: McGraw-Hill, 1956. First Polish translation: Selye H., Stres życia. Warsaw: PZWL, 1963.

2. Terelak JF. Człowiek i stres. Bydgoszcz: Oficyna Wyd. Branta, 2008. 